\title{
PERANCANGAN IDENTITAS VISUAL KAMPUNG KERAMIK DINOYO MALANG
}

\author{
Mahendra Wibawa \\ Prodi Desain Komunikasi Visual/STIKI Malang \\ mahendra@stiki.ac.id
}

\begin{abstract}
ABSTRAK
Setiap wilayah memiliki potensi yang dapat memberikan sumbangan terhadap pendapatan daerah dan berdampak pada tingkat kesejahteraan masyarakat. Meskipun demikian, hal tersebut hanya bisa terjadi apabila dilakukan secara sadar oleh seluruh stakeholder dan melalui program yang tepat sehingga identitasnya dapat dikenali oleh masyarakat. Perancangan ini bertujuan untuk menghasilkan identitas visual bagi kampung keramik Dinoyo Malang. Data dikumpulkan melalui metode wawancara dan pengkajian dokumen yang dianalisis dengan metode S.W.O.T. Perancangan ini menghasilkan sebuah GSM (Graphic Standard Manual) yang memuat Logo kampung keramik Dinoyo, tagline, beserta dua karakter Kerama dan Krani sebagai maskot dari kampung tersebut.
\end{abstract}

Kata Kunci: Destination Branding, Kampung Keramik

\begin{abstract}
Each region has the potential to contribute to regional revenue and the impact on the level of social welfare. Nevertheless, it can only happen if it is done consciously by all stakeholders and through appropriate programs so that their identity can be recognized by the public. This research aims to produce a visual identity for the Dinoyo Malang ceramic village. Data was collected through interview methods and document studies analyzed by the S.W.O.T method. This design produced a GSM (Graphic Standard Manual) that contained the Dinoyo ceramic village logo, tagline, along with two characters Kerama and Krani as the mascot of the village.
\end{abstract}

Keywords: Destination Branding, Ceramic Village

\section{PENDAHULUAN}

Merek tidak hanya dimiliki oleh sebuah produk atau jasa saja, namun kini sebuah daerah juga telah memiliki sebuah merek atau yang biasa disebut dengan Place Branding atau City Branding. Menurut Simon Anholt dalam Moilanen dan Rainisto (2009:7), City Branding adalah upaya pengelolaan citra dan perwajahan yang membutuhkan peran serta berbagai aspek seperti halnya faktor ekonomi, sosial, komersial, kultural, dan peraturan pemerintah. Indonesia sebagai daerah yang memiliki banyak kekayaan alam serta budaya juga tidak mau kalah untuk menawarkan potensi wisata yang dimiliki.

Pengembangan potensi suatu daerah, pariwisata nampaknya menjadi aspek andalan yang dikembangkan. Pariwisata merupakan salah satu sektor yang dapat meningkatkan pendapatan daerah, dikarenakan selain dapat menyerap tenaga kerja, pariwisata juga dapat menunjang pertumbuhan ekonomi bagi suatu negara dengan membantu peningkatan devisa. Alasan tersebut menjadikan pariwisata sebagai industri terbesar dengan pertumbuhan dan perkembangan tercepat.

Destination Branding merupakan usaha dalam merencanakan dan mengaplikasikan serta mengemas dengan baik terhadap suatu tujuan tempat wisata, sehingga akan bisa merubah persepsi orang terhadap suatu tempat atau tujuan, dan juga meningkatkan kesadaran khalayak umum terhadap tempat tersebut dengan segala perbedaan serta keunikannya, dan 
menunjukkan bahwa tujuan tempat tersebut wisata layak dan wajib dijadikan sebagai tujuan wisata favorit.

Sesuai dengan perkembangan seni kriya di Indonesia apa lagi perkembangan Seni Keramik adalah cabang seni rupa yang mengolah material keramik untuk membuat karya seni dari yang bersifat tradisional sampai kontemporer. Selain itu dibedakan pula kegiatan kriya keramik berdasarkan prinsip fungsionalitas dan produksinya. Sama halnya dengan sentra kampung keramik yang ada di Malang yang berpusat di Dinoyo, yang juga sebagai tempat berkembangnya keramik dan objek wisata di Malang.

Fokus perancangan ini adalah (1) Destination Branding Kampung Keramik (2) Perwujudan Konsep logo, konsep maskot, tagline. Perancangan ini bertujuan untuk menjelaskan secara deskriptif konsep destination branding. Hasil perancangan diharapkan dapat membantu warga disekitar kampung keramik Dinoyo untuk meningkatkan perekonomian dan membuat kampung keramik lebih dikenal oleh masyarakat luas dengan membuat maskot, logo, dan tagline.

Melalui studi kasus pada kondisi kampung keramik Dinoyo kota Malang peneliti melibatkan mahasiswa DKV STIKI Malang untuk melakukan penggalian data tentang potensi potensi yang dimiliki yang nantinya dapat digunakan sebagai dasar perancangan identitas visual. Sumber data terdiri dari data primer dan data sekunder. Data premier ini diperoleh dengan melakukan observasi langsung dan wawancara mendalam kepala ketua RT/RW, Ketua Paguyuban, toko - toko yang berada di wilayah Dinoyo dan wawancara kepada Masyarakat di sekitar Kampung Keramik. Sedangkan untuk data sekunder ini kami peroleh dengan mengutip sumber - sumber lain seperti data dari sumber pustakan seperti jurnal, hasil skripsi, internet dan sebagainya. Data tersebut bersifat melengkapi dan mendukung temuan yang didapatkan dalam proses observasi.

Setelah data didapat, maka langkah selanjutnya adalah mengolah data tersebut dengan menggunakan analisis SWOT sehingga secara komperehensif kebutuhan data untuk perancangan menjadi lebih mengerucut dan mempermudah proses visualisasi melalui pembuatan design brief.

Langkah selanjutnya adalah proses perancangan identitas melalui metode brainstorming dengan melakukan penggalian kemungkinan ditemukannya ragam subyek yang dapat digunakan sebagai insight perancangan. Berdasarkan insight tersebut thumbnail desain dapat divisualisasikan dan kemudian secara kreatif ditransformasikan menjadi tahapan rough sketch sebelum akhirnya menjadi desain final atau yang bisa disebut dengan comperehensif.

Bagan 1. Model Perancangan

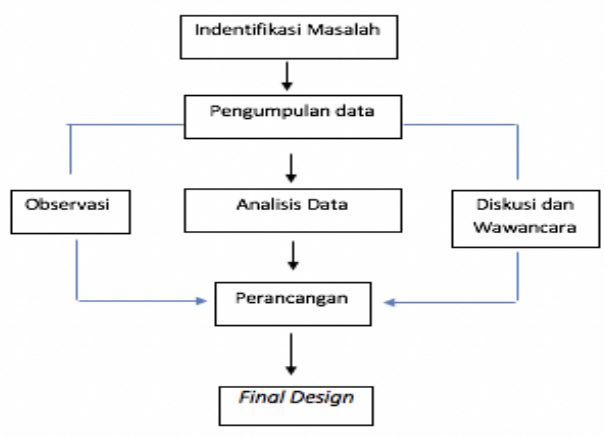




\section{PEMBAHASAN}

Berdasarkan data yang didapatkan terkait dengan kondisi dari kampung keramik Dinoyo, maka dirumuskan hasil analisis SWOT sebagai berikut:

a) Strength

- Banyaknya pengrajin keramik yang memiliki berbagai ciri khas.

- Jalan di kampung keramik merupakan jalan alternatif yang sering digunakan.

- Barang yang dijual sudah di export.

- Kampung keramik sudah di kenal

- Tempat edukasi

- Lokasi strategis

b) Weakness

- Akses jalan sempit namun cukup ramai

- Kurangnya publikasi

- Tidak ada sign system

- Kurangnya variasi produk

c) Opportunity

- Penggunaan pabrik bekas untuk, museum, dll

- Penambahan Sign System untuk mempermudah pengunjung

- Melanjutkan event yang ada secara rutin

d) Threats

- Banyak produk produk dari luar yang memiliki banyak variasi.

- Kurangnya minat pengunjung

- Jalan di kampung keramik sering macet

Dapat diambil kesimpulan bahwa pada dasarnya kampung keramik Dinoyo Malang ini memang sudah memiliki kesiapan, baik untuk sentra industri keramik maupun sebagai destinasi wisata khususnya wisata edukasi. Namun demikian karena keterbatasan infrastruktur dan media yang mendukung keberlangsungan eksistensi kampung keramik ini menjadi kurang dikenal oleh masyarakat.

\section{Konsep Pembuatan Logo}

Dalam pembuatan identitas, peneliti menggunakan dasar data yang didapatkan saat wawancara dan observasi. Melalui data tersebut, maka kata kunci yang digunakan untuk mengembangkan konsep-konsep visual yang merupakan ciri-ciri dan karakteristik dari kampung keramik Dinoyo Malang adalah alam, pekerja keras dan bersahabat. Berdasarkan ketiga kata kunci tersebut maka dikembangkan peta konseptual yang berupa brainstorming.

Penemuan insight daripada pengembangan brainstorming kemudian diwujudkan menjadi beberapa gambar sketsa hingga pada akhirnya melalui tahap diskusi dipilihlah salah satu desain logo yang mampu mewakili konsep tentang identitas kampung keramik Dinoyo. Logo dirancang memunculkan gaya tradisional Jawa Timur dengan visualisasi unsur 
alam, memiliki kesan ramah yang diimplementasikan pada penggunaan warna, namun dapat diimplementasikan di media apa saja.

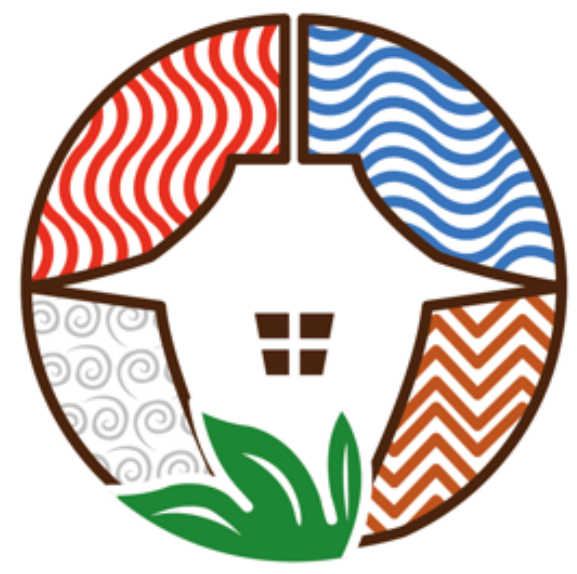

Gambar 1. Logo final kampung keramik Dinoyo Malang.

Logo ini menggambarkan 4 elemen, yang menjadi simbol dasar alam, dan juga merupakan bahan pembuatan dari keramik, yang di lambangkan dengan penggunaan warna merah, biru muda, biru tua, dan orange. Bentuk rumah adat jawa timur Joglo dihadirkan untuk melambangkan adat Jawa Timur yang secara simbolis juga menghadirkan konsep keramahan, terbuka dan mudah dikenali seperti yang teridentifikasi pada strength kampung keramik Dinoyo Malang. Elemen alam berupa tumbuhan pada logo ini bertujuan untuk menggambarkan unsur alam dan mewakili sifat ramah lingkungan.

\section{Konsep Pembuatan Tagline}

Tagline dirancang menggunakan bahasa Indonesia sehingga mudah dipahami dan meresap di benak masyarakat Indonesia pada umumnya sehingga mudah diingat. Meskipun demikian secara umum harus tetap melambangkan sifat asli masyarakat kampung keramik Dinoyo Malang.

\section{SATU TANGAN SERIBU KARYA}

Tagline ini memberikan sebuah gambaran yang jelas bahwa masyarakat di kampung keramik memiliki kreatifitas tanpa batas yang ditunjukkan dengan banyaknya ragam bentuk dan hias serta fungsi keramik yang dihasilkan di sentra industri tersebut. Lokasinya yang merupakan wilayah pemukiman warga tidak menghambat tingkat kreatifitas dan produktifitasnya. Kreatifitas tanpa batas dan tingkat produktifitas yang tinggi ini tertera dalam analisis strength yang mengungkapkan bahwa terdapat banyak bentuk dan ciri khas produksi yang dihasilkan oleh tiap pengerajin di kampung keramik Dinoyo.

\section{Konsep Font}

Font yang digunakan adalah "amazing infographic" dan dipilih sebagai font resmi karena memiliki karakter yang khas, tegas, namun juga ramah, dan mudah diingat. 


\title{
KAMPUNG KERAMIK \\ SATU TANGAN SEJUTA KERAMIK
}

\author{
ABCDEFGHIJKLM- \\ NOPORSTUVWXYZ \\ abcdefghijklm- \\ nopqrstuvwxyz
}

1234567890

$\sim * \$ \% *()-+=\mid \mathrm{H})]([:,<.>\mid$

Gambar 2. Font amazing infographic yang digunakan sebagai font resmi

\section{Konsep Pembuatan Maskot}

Dalam analisis SWOT masyarakat kampung keramik Dinoyo teridentifikasi memiliki kemampuan yang cukup terampil dan dikenal ramah. Produk keramik juga merupakan sebuah penggambaran proses yang penuh dengan kerja keras namun di dalamnya terkandung unsur-unsur kelembutan yang erat dengan konsep keramahan. Oleh karena itu personifikasi sosok keramik dianggap tepat untuk mewakili gambaran ideologi, semangat kerja dan spiritual warga kampung keramik Dinoyo Malang, sehingga lahirlah maskot yang diberi nama Kerama

Sementara itu penggambaran aspek spiritual yang mampu menjadikan motivasi bagi masyarakat dalam berkarya diwujudkan dalam bentuk makhluk yang lebih bersifat paranormal. Hal ini adalah hal yang wajar dalam konteks budaya dunia yang biasanya diwakili oleh makhluk yang memiliki dimensi yang berbeda dengan manusia. Dalam berbagai agama di dunia pun memiliki konsep yang sama sehingga manusia mengenali konsep peri, malaikat, danyang, dan lain sebagainya. Inilah yang menjadi dasar penciptaan maskot yang diberi nama Kerani.

Kerama adalah makhluk yang terbuat dari limbah keramik yang berbentuk pot yang kokoh, namun masih berubah ubah jika ada Kerani. Sedangkan Kerani adalah arwah (wisp) yang melambangkan karakter yang kreatif, penuh ide, dan mengikuti perkembangan jaman. Warna kuning pada kerama melambangkan semangat aktif, ramah, dan hangat. Sedangkan biru pada Kerani melambangkan kreatif, penuh ide, dan mengikuti perkembangan jaman.

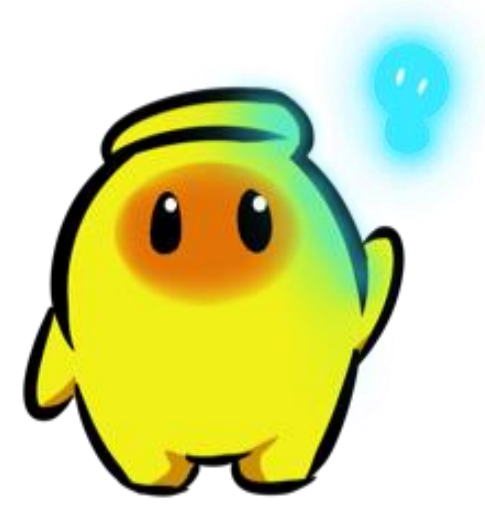




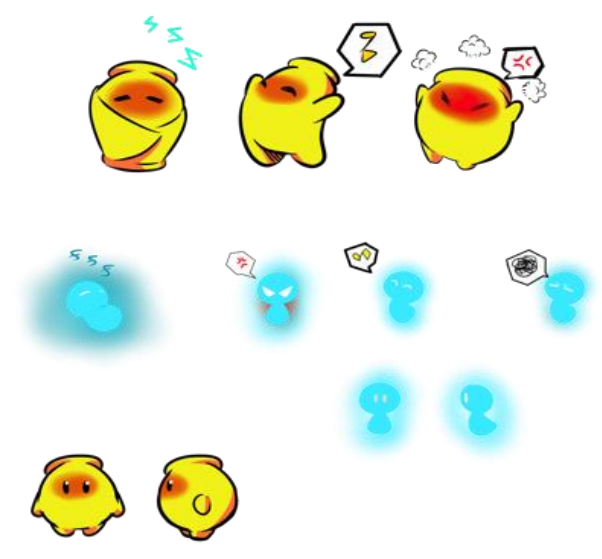

Gambar 3. Maskot kampung keramik Dinoyo

\section{KESIMPULAN}

Identitas visual sebuah daerah sebagai salah satu elemen yang diperlukan dalam program Place Branding dirancang berdasarkan berbagai aspek yang mampu menggambarkan keadaan sosial, budaya, dan semangat dari wilayah tersebut melalui potensi-potensi yang kemudian diwujudkan baik secara ikonik maupun simbolik. Berdasarkan data yang sudah didapatkan melalui analisis SWOT maka didapatkan hasil perancangan logo sebagai identitas visual beserta maskot Kerama-Kerani sebagai ambassador dari kampung keramik Dinoyo Malang yang dirancang berdasarkan aspek-aspek yang tersebut. Visualisasi desain identitas kampung keramik Dinoyo ini tertuang dalam Graphic Standar Manual atau GSM yang dapat digunakan sebagai buku panduan penggunaan logo dan maskot.

\section{DAFTAR PUSTAKA}

ADGI. (2017). "Strategi Pengembangan Destinasi Wisata Berbasis Kampung (Studi Kasus: kampung DAM Sekabrom Malang)". Malang Chapter. Project portofolio. Ahmad, A.P.S. (2013). "Studi Perancangan Identitas Visual Wilayah Karimunjawa”. Jurnal Humaniora (Vol 4 No 1), Hlm 567-579.

Bappeda Kota Malang. (2007). "Kajian Pengembangan Potensi Lokal Kota Malang” (laporan). https://bappeda.Malangkota.go.id/wpcontent/uploads/sites/11/hasil_kajian/BUKU\%20KAJIAN.pdf . Diunduh tanggal 3 Juni 2018.

Hadiati, Sri. (2008). "Perilaku Wirausaha Industri Keramik Berskala Kecil untuk Meningkatkan Daya Saing Produk di Malang”. Jurnal Manajemen dan Kewirausahaan (Vol. 10, No. 2), Hlm. 115-123.

Moilanen, T. \& Rainisto, S. (2009) "How to Brand Nations, Cities and Destinations" (ebook). Palgrave MacMillan.

Nurcahyo, I.F dkk. (2016). "Panduan Pendirian Usaha Kriya Keramik" (e-book). Jakarta. Bekraf. Diunduh tanggal 3 Juni 2018.

Santoso, J.T. Dkk. (2016). "Pola Aktivitas Wisata Belanja di Kampung Wisata Keramik Dinoyo Malang”. Jurnal Tesa Arsitektur (Vol 14, No. 1). Diunduh tanggal 3 Juni 2018. 